\title{
Article \\ Relationship between Wildfire Smoke and Children's Respiratory Health in the Metropolitan Cities of Central-Chile
}

\author{
Rebecca Ciciretti ${ }^{1}$, Francisco Barraza ${ }^{2}$, Francisco De la Barrera ${ }^{3,4}$ (D) , Lorna Urquieta ${ }^{5}$ and Sandra Cortes ${ }^{1,4,6, *(1)}$ \\ 1 Departamento de Salud Pública, Facultad de Medicina, Pontificia Universidad Católica de Chile, Diagonal \\ Paraguay 362, Piso 2, Santiago 8330077, Chile; rebecca.ciciretti@gmail.com \\ 2 School of Geography, University of Otago, Dunedin 9016, New Zealand; francisco@otago.ac.nz \\ 3 Faculty of Architecture, Urbanism and Geography, University of Concepcion, Concepción 3349001, Chile; \\ fdelabarrera@udec.cl \\ 4 Center for Sustainable Urban Development (CEDEUS), Pontificia Universidad Catolica de Chile, \\ Santiago 340, Chile \\ 5 Servicio de Salud Valparaíso San Antonio, Valparaíso 1435, Chile; lorna.jara.u@gmail.com \\ 6 Advanced Center for Chronic Diseases (ACCDis), Pontificia Universidad Católica de Chile, De Chile, \\ Santiago 340, Chile \\ * Correspondence: scortesn@uc.cl
}

check for

updates

Citation: Ciciretti, R.; Barraza, F.; De la Barrera, F.; Urquieta, L.; Cortes, S. Relationship between Wildfire Smoke and Children's Respiratory Health in the Metropolitan Cities of

Central-Chile. Atmosphere 2022, 13, 58 . https://doi.org/10.3390/

atmos13010058

Academic Editors: Gunther Paul,

Saidul Islam and Ilias Kavouras

Received: 4 October 2021

Accepted: 25 December 2021

Published: 30 December 2021

Publisher's Note: MDPI stays neutral with regard to jurisdictional claims in published maps and institutional affiliations.

Copyright: (c) 2021 by the authors Licensee MDPI, Basel, Switzerland. This article is an open access article distributed under the terms and conditions of the Creative Commons Attribution (CC BY) license (https:/ / creativecommons.org/licenses/by/ $4.0 /)$.

\begin{abstract}
Wildfire causes multiple problems for people living in cities. One of them is the deterioration of air quality as a result of wildfire smoke. This smoke can consequently have effects on human health. The present study aims to characterize the relationship between the occurrence of wildfires in central Chile and the effects on children's respiratory health. Public databases provided the number of emergency care visits, wildfires, and concentration of air pollutants, demographics and meteorological variables for the regions of Santiago and Valparaiso from 2010 to 2013. Time series analysis was used monthly on health care visits to determine the relative health risk in children when in the presence of additional wildfires. Significant health risks were observed in Santiago for children younger than 1-year-old of bronchitis (RR 1.007, CI 95\% 1.007-1.008; chronic lower respiratory diseases (RR 1.012, CI 95\% 1.012-1.013); and pneumonia (RR 1.026 CI 95\% 1.026-1.027) and in children aged one to four years old (RR 1.016 CI 95\% 1.015-1.016). A dose-response relationship was also observed for pneumonia, showing that it affects younger children particularly when there is an increase in the number of wildfires. In the Region of Valparaíso, wildfires did not significantly change the risk of respiratory illness, this could be due to favorable ventilation. Currently, Santiago has an urgent need for monitoring and the evaluation of the damage to children's respiratory health, along with the development of comprehensive prevention strategies.
\end{abstract}

Keywords: wildfires; Chile; air quality; climate change; children's health

\section{Introduction}

Air pollutants released as a consequence of the nature and quantity of biomass burned in wildfires [1] are able to cause problems to human health. Particulate Matter (PM 2.5 and $\mathrm{PM}_{10}$ ) is one of the most relevant key components with a plausible impact on human health [2]. While the effects of air pollution on the respiratory system are felt by children and adults alike, the effects are exacerbated in children, because they have lesser-developed immune and respiratory systems, smaller lungs, and a higher proportion of lung surface to the amount of air inhaled [3]. In this group, there is a greater possibility of a significant accumulation of toxicants in the lungs during a period of higher air contamination [4]. The exposure to particulate matter released from wildfires has been associated with several health effects, ranging from higher consumption of medications [5], nose and throat irritations [6,7] to more serious disorders, such as asthma exacerbation, pulmonary circulation, bronchitis, chronic obstructive pulmonary disease, cardiovascular disease, ischemic heart 
disease, cerebrovascular disease and premature death [1,6,8-12]. All of these consequences have turned wildfire smoke into a paramount health issue affecting millions of people in climate change context [13].

Studies on the effects of wildfires on respiratory illnesses are more limited in scope, and there is a need to increase the visibility of these detrimental effects so that precautions can be taken to protect children from harm. Because of the small size of the breathable particulate matter, the effects of wildfire smoke are not limited to the vicinity of the fires. They can be dispersed over hundreds of kilometers and reach far downwind to densely populated areas, increasing mortality and morbidity rates $[9,14,15]$.

\subsection{Wildfires in Chile}

Wildfires are a frequent phenomenon in Central-Chile and in its austral Mediterranean landscapes, however large magnitude wildfires are not [16]. In the last two decades, the combination of the landscape modification to monoculture in addition to climate change triggers an increase in frequency, severity and burned areas, including large magnitude wildfires during the austral summer [17,18]. Indeed, in the year 2017, in Chile, the most intense landscape fire was registered on Earth at this date [19]. After this mega-disaster, the discussion turned to the structural causes of this phenomenon where three themes became relevant arguments for investing in prevention. One was the intentional or accidental ignition of fires which highlighted the importance of avoiding the action of pyromancers. The other was oriented to the little knowledge and awareness about effects on people, beyond the material losses or deaths. Additionally, there were discussions focused on whether the current landscape setting which is dominated by massive exotic pyrophyte forest plantations facilitates the occurrence of large wildfires $[19,20])$ including the need of including actions for fire prevention such as prescribed fires, and mechanical treatments [17].

In 2017, an estimate of $74 \%$ of the Chilean population (nearly 13 million people that year) were exposed to an unusual increase in particulate matter levels due to wildfire smoke [17]. Currently, there is no active discussion in the country about the impacts of wildfires on human health. The available information is limited to the direct effects, such as burned areas, damage of buildings and number of dead firefighters [19]. Only one study presents an indirect calculation of impacts of $\mathrm{PM}_{2.5}$ from smoke on health; where their results show small increases in premature deaths, respiratory hospital admissions and cardiovascular hospital admissions during 2017 wildfires [14,19].

We do not know the implications on population health in countries in development processes or in which their development depends on the extraction of natural resources (including forest production); even less has been described about these changes associated with meteorological variabilities'. A more accurate relationship study of wildfire smoke with health problems is still in need in Latin American countries, which could contribute to evaluating all the negative effects and risks of wildfires, to develop new policies concerning fire control and surveillance [13] and to give support to higher-risk populations, such as children, the poorest and those living in developing countries [21].

\subsection{Study Objective}

This preliminary study characterizes the baseline risk in children's respiratory health from 2010 to 2013, a period in which no fires of significant relevance have been observed in the Central zone of Chile. It is the first study of its kind in Chile and has a baseline perspective to help understand the impact on human health from wildfire smoke.

\section{Methods}

\subsection{Study Area}

Santiago and Valparaiso regions are located in Central Chile $\left(33^{\circ} 15^{\prime} \mathrm{S} 71^{\circ} 10^{\prime} \mathrm{W}\right)$. Together, they cover more than $15,000 \mathrm{~km}^{2}$ following fast and continuous urbanization with a population of over 9.1 million inhabitants [22]. Both sites are subtropical places defined geographically by the influences of the Pacific Ocean, the Andes and Coastal mountain 
ranges [23]. They are also characterized by significant inter-annual variability connected to El Niño Southern Oscillation (ENSO) and longer-term variability associated with the Pacific Decadal Oscillation [24]. Since 2010, central and southern Chile have been affected by drought, partly caused by natural variability and partly linked to a global warming trend $[25,26]$.

In these regions, the highest levels of PM and other air contaminants are found during the austral winter and autumn as a result of the thermal inversion layer and the country's topography, together with the increase in pollution released from industries and from residential heaters [27]. It is in this season that most severe health problems in emergency department visits are found, for example, non-accidental daily mortality, cardiorespiratory mortality, chronic obstructive pulmonary disease (COPD), venous thromboembolic disease, epilepsy, acute complications of diabetes and wheezing illnesses [28-34]. On the other hand, during the austral summer and spring, the air quality improves with the exception of wildfire episodes [17].

\subsection{Study Design and Data}

In order to achieve our goal, an epidemiological study performed with time-series and geographical comparisons was completed. The units of analysis were months of the year, from 2010 to 2013. The geographical units correspond to two regions: Santiago and Valparaíso. More than $85 \%$ of valid data were collected from both sites.

Wildfire data were collected from the National Forest Corporation (CONAF) [35] getting the monthly frequency of all types of wildfires. Human-made fires (intentional and accidental), naturally occurring fires, and controlled burns were all included in the data. Since the primary focus of the study was to understand the relationship between fire smoke and respiratory health, no differentiation was made between the types of fires. Each regional information was consolidated from the district level provided by CONAF.

Fire smoke pollution proxy was used 24-h a day. $\mathrm{PM}_{10}$ data from the National Air Quality Information System (SINCA, https: / / sinca.mma.gob.cl/ , last access 30 July 2015) provided average to monthly levels. Meteorological information was taken from the Chilean Meteorological Directorate (DMC, http:/ / www.meteochile.cl, 30 September 2015), who work under the World Meteorological Organization standard, including meteorological parameters of daily temperature (maximum, minimums, and averages), precipitation, relative humidity, and wind speed.

Health information was extracted from the Department of Statistics from the Ministry of Health (DEIS, http:/ / www.deis.cl/, last access 30 November 2015). The emergency consultation for upper respiratory infections, bronchitis (J20-21), chronic lower respiratory disease (J40-46), acute upper respiratory infection (J00-06), and pneumonia (J12-18), using ICD10 were collected from emergency care visits at primary health level units for the age groups of: <1 year old, 1-4 years old, and 5-14 years old.

\subsection{Statistical Analyses}

To evaluate the possible association between the monthly number of emergency consultations with the $\mathrm{PM}_{10}$ and the number of fires, a multivariate analysis was performed using a mixed generalized additive model (GAM) for each respiratory consultation. These variables were logarithmically transformed as response variables and for both regions independently. The use of this model allows us to establish relative risk estimations through a cubic or natural regression spline, as found in the literature [36]. All calculations were performed in the R software, using the GAM function of the " $\mathrm{mgcv}^{\prime}$ library. The proposed multivariate model is as follows:

$$
\log u_{t}=\beta_{0}+\beta_{1} \text { PM10 }+\beta_{2} \text { Fires }+\beta_{3} \text { Temp }+\beta_{4} \text { Precip }+f(t ; \lambda)+\log \left(\text { Pop }_{t}\right)
$$

In the above equation: 
- The parameter " $u_{t}$ " is the outcome (dependent) variable and corresponds to the monthly number of Health Emergency at time " $t$ " on the period 2010-2013;

- $\quad \mathrm{PM}_{10}$ " is the ambient $\mathrm{PM}_{10}$ concentration in micrograms per cubic meters;

- $\quad$ "Fires" is the monthly number of fires in the studied area;

- $\quad$ "Temp" and Precip" are the ambient temperature $\left({ }^{\circ} \mathrm{C}\right)$ and precipitations ( $\mathrm{mm} /$ hours), respectively;

- $\quad f(t ; \lambda)$ is a smoothing function;

- $\quad$ "Popt" is the population density;

- $\quad$ " $\beta$ ' $s$ " are the calculated regression parameters, used to estimate Relative Risks.

The independent variables used were: the monthly number of wildfires, $\mathrm{PM}_{10}$ concentration, population density, and meteorological variables. To interpret the association of emergency visits with the number of fires, adjusted for the other variables, the estimate of $\beta 2$ was amplified for every 5 fires.

Emergency consultation rates were determined for children according to the following age-groups; < 1 year, 1-4 years, and 5-14 years old and type of illness, utilizing the total population for that age group and region, with a selected amplifier corresponding to 1000 inhabitants. This analysis assumes that the distribution of the monthly emergency care visits for respiratory issues is the random variable within a Poisson distribution, with the confounding meteorological variables as monthly average temperature and monthly accumulated precipitation. The primary reason for the utilization of this type of model is that the relationship between Particulate Matter concentration and emergency care visits is not linear. It is known that during the seasons with lower temperatures, the levels of particulate matter are higher compared to the seasons with higher temperatures. In the case of forest fires, the opposite occurs, where the highest numbers of wildfires are produced in the seasons with higher temperatures. This is why it is imperative to consider the season of exposure to obtain estimates that are closer to reality.

\section{Results}

\subsection{Ambient Parameters and Wildfires Trend for Santiago and Valparaiso Regions}

The results are separated by administrative regions since differences are remarkable. Santiago presents the largest summer and winter $\mathrm{PM}_{10}$ levels and did not present episodes of precipitation during summers. Meteorological parameters did not have significant differences between both regions except for summer precipitation in Valparaiso, which presented around $21 \mathrm{~mm}$ of rain during this season. A summary of the general characteristics is given in Table 1 for both regions.

Table 1. Air pollution in summer or winter seasons, meteorological conditions and number of total populations of the Regions of Valparaíso and Santiago, from 2010 to 2013.

\begin{tabular}{ccccc}
\hline & \multicolumn{2}{c}{$\begin{array}{c}\text { Valparaíso } \\
\text { Region }\end{array}$} & \multicolumn{2}{c}{$\begin{array}{c}\text { Santiago } \\
\text { Region }\end{array}$} \\
\hline & Median & IQR & Median & IQR \\
\hline Concentration $\mathrm{PM}_{10}$ in summer $\left(\mu \mathrm{g} / \mathrm{m}^{3}\right)$ & 46.9 & 9.2 & 55.5 & 13.6 \\
Concentration $\mathrm{PM}_{10}$ in winter $\left(\mu \mathrm{g} / \mathrm{m}^{3}\right)$ & 42.9 & 7.2 & 74.0 & 20.8 \\
Temperature in summer $\left({ }^{\circ} \mathrm{C}\right)$ & 18.3 & 1.1 & 20.4 & 2.0 \\
Temperature in winter $\left({ }^{\circ} \mathrm{C}\right)$ & 12.8 & 1.1 & 8.9 & 2.3 \\
Precipitation in summer $(\mathrm{mm} /$ station) & 21.3 & 23.0 & 0.0 & 0.0 \\
Precipitation in winter $(\mathrm{mm} /$ station) & 75.5 & 43.1 & 79.1 & \multicolumn{2}{c}{100,202} \\
Population at risk $<1$ year (Number) & \multicolumn{2}{c}{23,580} & \multicolumn{2}{c}{397,375} \\
Population at risk 1 to 4 years (Number) & \multicolumn{2}{c}{93,111} & \multicolumn{3}{c}{964,422} \\
Population at risk 5 to 14 years (Number) & \multicolumn{2}{c}{239,915} & \multicolumn{3}{c}{}
\end{tabular}

From January 2010 to December 2013, 3395 wildfires were registered in Valparaiso and 1567 in Santiago. Both regions present a seasonal pattern with the highest number of fires 
during the austral summer and an almost absence of fires in winter. The severest months were December, January and February with more than $60 \%$ of the total wildfires (Figure 1).

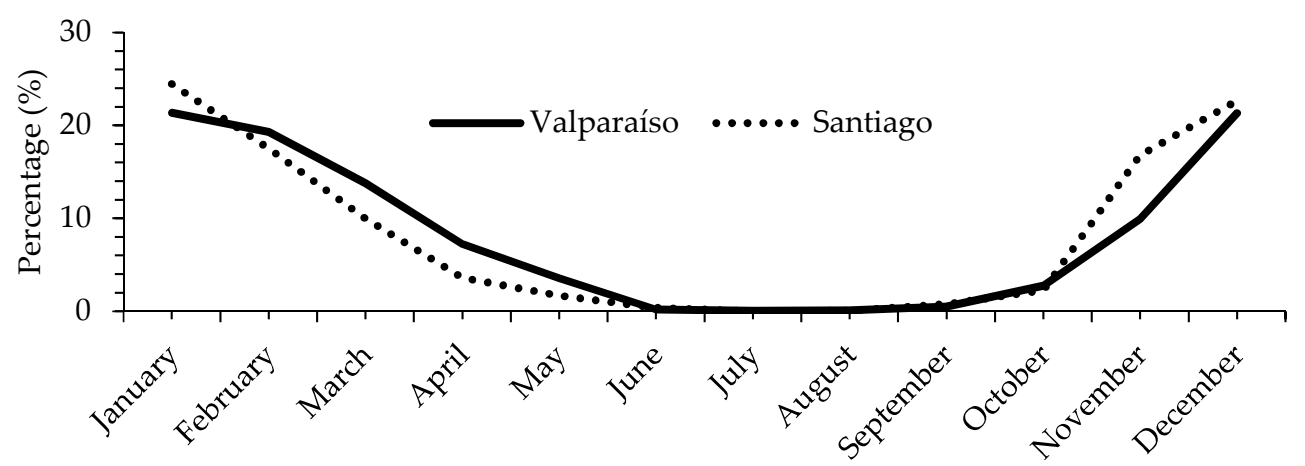

Figure 1. Wildfire occurrences in Valparaiso and Santiago regions from 2010 to 2013 (Monthly percentage).

Annual trend was not observed, with similarities in the number of fires in both regions; however, Santiago's summer of 2011 showed a large number of fires compared with the other studied years. During the four studied years, Valparaiso had the maximum number of fires per month in December 2010 (229 fires) and Santiago had them in January 2011 (159 fires) (Figure 2).

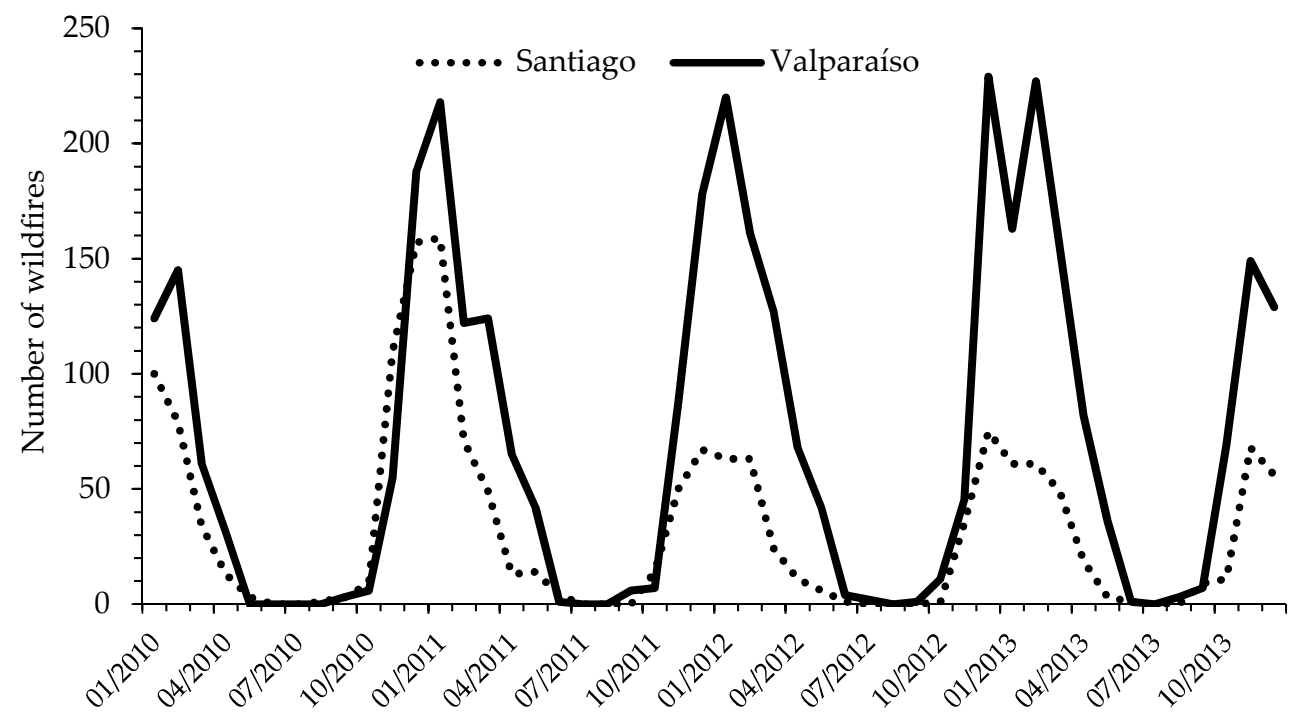

Figure 2. Temporal trend of the number of wildfires in Valparaíso and Metropolitan regions from January 2010 to December 2013.

In relation to air pollution, $\mathrm{PM}_{10}$ showed lower mean levels in the summer months than in the winter. Concentrations were significantly higher in the Santiago region than in Valparaiso, even in summer (Figure 3). 


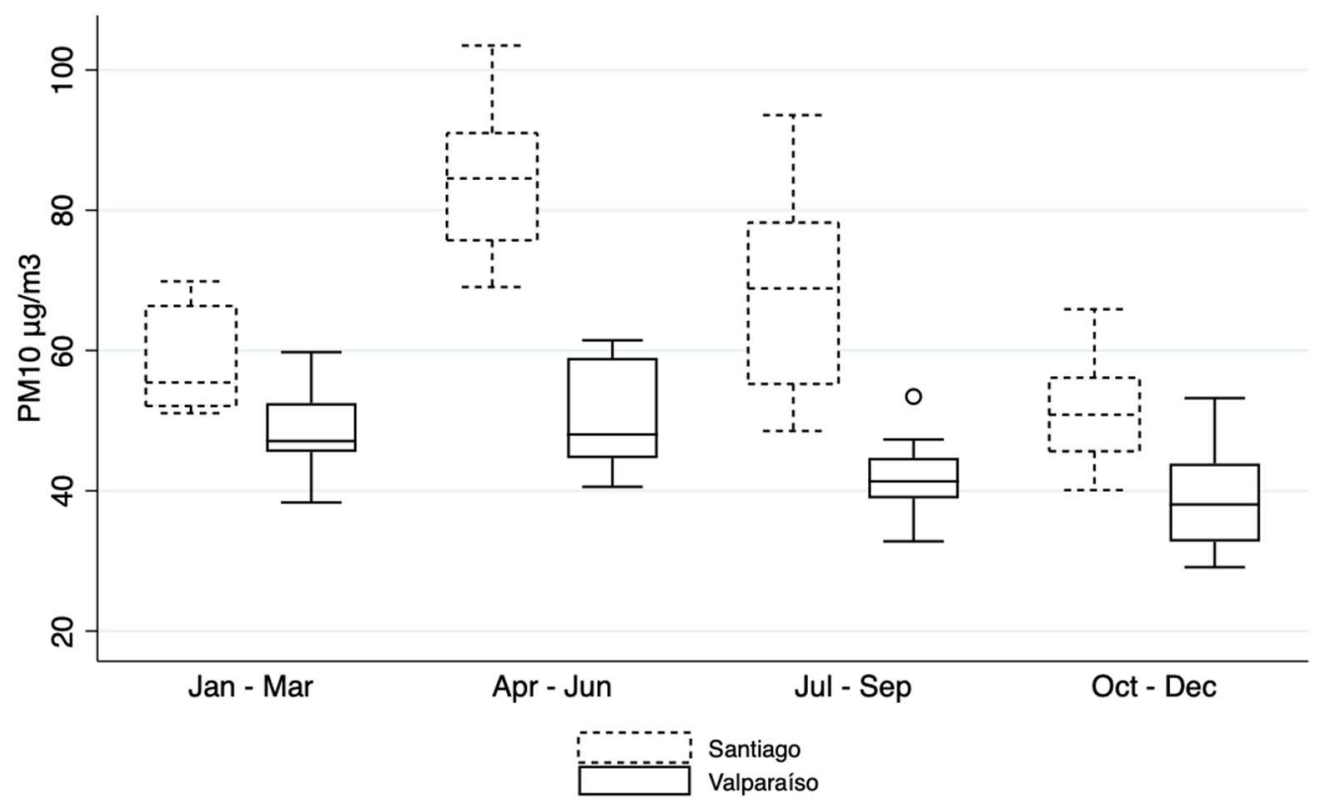

Figure 3. Temporal trend of the Particulate Matter $\left(\mathrm{PM}_{10}\right)$ by trimester in the Valparaíso and Santiago regions from January 2010 to December 2013.

\subsection{Risk Estimation of Respiratory Illness}

Santiago (Table S1) showed significant impacts of wildfires on children's health during 2010 and 2013, after an occurrence of five wildfires. This region presented in children $<1$ year: (i) an increase of $0.7 \%$ in the emergency consultations for bronchitis (RR 1.007 CI 95\% 1.007-1.008), (ii) an increase of 1.2\% in emergency consultations for chronic lower respiratory disease (RR 1.012 CI 95\% 1.012-1.013), (iii) an increase of $2.6 \%$ in pneumonia emergency consultations (RR 1.026 CI 95\% 1.026-1.027), and finally in children between one and four years, an increase of $1.6 \%$ in pneumonia emergency consultation (RR 1.016 CI 95\% 1.015-1.016) after applying an exponential function for the estimated coefficient linked to fire, considering a number of five wildfires per month (Table 2). Valparaiso did not show significant impacts (Table S2).

Table 2. Associations among wildfires on respiratory emergencies in Valparaiso y Metropolitan region from 2010 to 2013 (as Relative Risk and Confidence Interval at 95\%). Model for emergency diagnosis according to PM10 and number of fires, adjusted for variable meteorological variables (temperature and precipitations).

\begin{tabular}{|c|c|c|c|c|c|}
\hline \multirow[b]{2}{*}{ Emergency Diagnosis } & \multirow[b]{2}{*}{ Age Stratum * } & \multicolumn{2}{|c|}{ Valparaiso } & \multicolumn{2}{|c|}{ Santiago } \\
\hline & & $\mathbf{R R}$ & $95 \%$ CI & $\mathbf{R R}$ & $95 \%$ CI \\
\hline \multirow{3}{*}{ Bronchitis (J20-21) } & $<1$ & 0.997 & $0.996-0.998$ & 1.007 & $1.007-1.008$ \\
\hline & 1 to 4 & 0.984 & $0.983-0.984$ & 0.992 & $0.992-0.993$ \\
\hline & 5 to 14 & 0.977 & $0.977-0.978$ & 0.978 & $0.978-0.979$ \\
\hline \multirow{3}{*}{$\begin{array}{c}\text { Chronic lower respiratory } \\
\text { disease }(\mathrm{J} 40-46)\end{array}$} & $<1$ & 0.994 & $0.994-0.995$ & 1.012 & $1.012-1.013$ \\
\hline & 1 to 4 & 0.985 & $0.985-0.985$ & 0.996 & $0.996-0.996$ \\
\hline & 5 to 14 & 0.972 & $0.972-0.973$ & 0.980 & $0.979-0.980$ \\
\hline \multirow{3}{*}{$\begin{array}{l}\text { Acute upper respiratory } \\
\text { infection (J00-J06) }\end{array}$} & $<1$ & 0.990 & $0.990-0.990$ & 0.988 & $0.988-0.988$ \\
\hline & 1 to 4 & 0.985 & $0.985-0.985$ & 0.984 & $0.983-0.984$ \\
\hline & 5 to 14 & 0.980 & $0.980-0.980$ & 0.981 & $0.981-0.981$ \\
\hline \multirow{3}{*}{ Pneumonia (J12-18) } & $<1$ & 1.000 & 0.999-1.001 & 1.026 & $1.026-1.027$ \\
\hline & 1 to 4 & 0.990 & $0.989-0.990$ & 1.016 & $1.015-1.016$ \\
\hline & 5 to 14 & 0.992 & $0.991-0.993$ & 0.999 & 0.999-1.000 \\
\hline
\end{tabular}

*in years. 


\section{Discussion}

Over the four studied years (January 2010 to December 2013), a total of 4962 wildfires were recorded for Valparaiso and Santiago regions; the number of fires in Valparaiso was much higher than in Santiago. However, Santiago's children presented a higher risk of developing a respiratory disease due to the exposure to wildfire smoke. This behavior could be explained by the air pollutant dispersion from coastal sites to Santiago and by its topography. Cuchiara et al. [14] proved with dispersion models that a relevant increase in air pollution concentration from biomass-burning originated in western wildfires, where Valparaiso is located. Moreover, particularly during summer, there is an el radiated driven circulation that defines up-slope south-westerly winds in the afternoon and down-slope north-easterly winds at night and morning hours [27,37]. On the other hand, Santiago is located in a basin shape area confined between two mountain ranges, which increases the residence time of the air pollutant.

Our study examined the effects of wildfires on respiratory health, primarily centered on children, and determined that the older age groups (5-14 years) were less prone to respiratory distress, in contrast to the studies conducted by several authors $[10,11,38,39]$ that were inconclusive on the results of age effects. In Johnston et al., the association between smoke events in Sydney, Australia and respiratory illnesses was examined utilizing a timestratified case-crossover design in which hospital emergency department (ED) attendance, exposure data $\left(\mathrm{PM}_{2.5}\right.$ or $\left.\mathrm{PM}_{10}\right)$, and meteorological covariates of interest were compared. While the study recognized a higher exposure risk for children, it determined a greater association between smoke events and ED attendance for adults [10]. Similarly, Delfino et al. examined the relationship of hospital admissions for respiratory issues during the California forest fires in 2003 through the comparison of average $\mathrm{PM}_{2.5}$, hospital admissions, and meteorological covariates. These authors determined that the period during and after the forest fires was associated with increased hospital admissions for respiratory issues for all age groups [38]. Another study on the 2003 California fires utilized a questionnaire-based investigation in two existing cohorts of school-aged children in which participants were asked about fire smell indoors, asthma attacks, and irritated eyes, among other symptoms. While the study results were based highly in response to the questionnaires, it determined an increase in various symptoms in communities directly affected by the fires [39]. A study by Reid et al. of the California forest fires in 2008 examined the relationship of hospital admission visits with $\mathrm{PM}_{2.5}$ exposure data and meteorological covariates, among others, and determined a greater effect in adults (ages 20-64) compared to children or older adults. Although the study determined that $\mathrm{PM}_{2.5}$ levels were highest during the fire, hospital admissions were highest before the fire [11]. These differences could be explained, in part, for the use of different epidemiological methods and also for the effects of additional variables related to social context not comparable among the studies. The majority of these studies were made in developed countries.

Various studies agree that individuals of all ages with pre-existing conditions, such as asthma, are more prone to respiratory distress and prevention strategies should be taken for all people to mitigate the potential effects of wildfires on respiratory health and mental health $[40,41]$. Although it is recognized that children and older adults constitute more vulnerable populations [42], in developing countries, and in Chile, there is limited evidence on chronic diseases in children and young people. In Chile, a high occurrence of nutritional, metabolic, and respiratory disorders have been described [43-45]. This deleterious baseline state of health could be aggravated in those populations increasing the demand for health care in periods also affected by forest fires and an increase in the concentration of particulate material [46]. Despite the impact of fires 2010-2013 on pollution and health can be estimated as low when compared to winter events of pollution, it is relevant in the local context where wildfires are not recognized as a source of pollution and health problems. Under the occurrence of megafires, the effects could be remarkably higher [17]. 


\subsection{Strengths and Limitations of Our Study}

This study was focused on the relationship between wildfires, air pollution and their effect on children's respiratory health, infrequent in the literature [13] and also covering a highly populated area in Chile. Results call the attention of the greater need for specialized study on children's health as the resulting accumulation of toxicants during periods of higher air contamination can be detrimental to health in early ages, affecting the prevalence of chronic diseases along the rest of life [13].

One of the limitations of the present study was the limited data regarding wildfire data, emergency consultations, and air contamination for Chile, wherein the best availability of data was for Santiago and Valparaiso regions. Further studies should consider large scale datasets. Another limitation is that the air pollutants criteria are typically utilized as a proxy for wildfire smoke exposure. Wherein only values for $\mathrm{PM}_{10}$ were readily available from SINCA (National Air Quality Information System) for both regions. In this regard, it needs to be acknowledged that $\mathrm{PM}_{2.5}$ air pollution data would provide a more accurate reflection of respiratory distress among children since these particles are able to penetrate deeper into the lungs as a result of their size [47].

In addition, there are other important pollutants, such as hazardous air pollutants (HAP), which can have detrimental effects on respiratory health, or other chemical agents from wildfire smoke, not evaluated in this study, which could change the risk of respiratory distress in children. Additionally, it is important to note that it is difficult to determine if the air pollution during these periods can only be attributed to wildfires, when they could also be caused by other sources or if the exposition is mediated by socioeconomic disparities. These kinds of socioeconomic conditions are not usually collected in the dataset of emergency consultations.

\subsection{Wildfires and Climate Change}

Climate change is causing more drastic meteorological conditions that increase the risk of wildfires around the world. Drier and hotter conditions result in faster-spreading fires, deriving on higher levels of air contamination, and greater inhalation of particulates by people $[47,48]$. Although forest fires have significant environmental consequences around the world, the greatest concern to human health arises when forest fires occur near heavily populated areas. Despite the fact that wildfire smoke can dissipate slightly in the atmosphere, the results of this study and previous ones prove that wildfire smoke can affect populated areas located far away of the wildfires, resulting in increased smoke inhalation and respiratory distress. Since children spend significant amounts of time outdoors, the effects of smoke inhalation are exacerbated in these populations. As a result, it is crucial that steps are taken to mitigate the effects of climate change, especially those linked to wildfires, and to better understand the detrimental effects of wildfires on children's respiratory health.

\section{Conclusions}

This novel study in Chile provides evidence of the impact of wildfires on public health, particularly on children's respiratory health. During the studied summers, more than 1 million children living in Santiago presented an increase in the risk of developing respiratory illness, due to exposure to wildfire smoke. It is evident from this study that basin shape geography exhibiting poor ventilation is not only affected by the poor air quality in the winter and autumn but is also affected during the warmer season due to the presence of wildfire smoke. In the case of Santiago, located in a basin shaped valley, efforts should be made to prevent, control, and mitigate damages to children's health due to the increasing occurrence of wildfires.

As well as several other countries in the Latin American region, in Chile the occurrence of fires and their impacts on population health are expected to increase due to changes in the climate. In a preventive way, it is necessary to strengthen the sanitary and environmental surveillance systems of these events. However, advanced research is urgently required in 
those communities where fires are concentrated year after year. Future interdisciplinary research should improve the measurement of exposure to toxic compounds released during the wildfires and execute more specific measurements of the various health damages, including vascular alterations, skin disorders, injuries and even mental health at the community level. It should be prioritized in the most vulnerable populations such as pregnant women, children, and people with other vulnerabilities or even workers in the most affected areas. This research will hopefully influence other developing countries, especially those with a similar deterioration of air quality as Chile, rapid growth and weak regulation on wildfire control.

Supplementary Materials: The following are available online at https://www.mdpi.com/article/ 10.3390/atmos13010058/s1, Table S1. Rates of respiratory illness (emergency consultations per 1000 inhabitants) according to CIE10, for children under 14 years all and living in Valparaiso from 2010 to 2013, Table S2. Rates of respiratory illness (emergency consultations per 1000 inhabitants), according to CIE10, for children under 14 years all and living in Santiago from 2010 to 2013.

Author Contributions: Conceptualization, S.C. and R.C.; methodology, R.C., L.U., S.C.; software, L.U., F.B., F.D.1.B.; validation, F.D.1.B., F.B.; formal analysis, S.C., F.B. and F.D.l.B.; investigation, R.C. and L.U.; resources, S.C.; writing — original draft preparation, R.C., L.U.; writing—review and editing, F.B., F.D.l.B. and S.C. All authors have read and agreed to the published version of the manuscript.

Funding: This study was funded by funded by the United States Fulbright Student Program in Chile and the Chilean Ministry of Health's Scholarship on Public Health through the Pontificia Universidad Católica de Chile. Additional support was received from Agencia Nacional de Investigación y Desarrollo (ANID) through the Advanced Center for Chronic Diseases (ACCDis) (FONDAP 15130011) and CEDEUS (FONDAP 15110020) and FONDECYT 11190530.

Institutional Review Board Statement: Not applicable.

Informed Consent Statement: Not applicable.

Data Availability Statement: Not applicable.

Acknowledgments: We want to thank Kristie Trousdale from the Children's Environmental Health Network for her review of the paper, Claudio Vargas y Maria José Ojeda for their support in the analysis of data, and the National Forest Corporation (CONAF), especially the Executive Director, Aaron Cavieres, and Claudia Tobar. The authors also acknowledge Elinor Vargas for English edition and grammatical contributions.

Conflicts of Interest: The authors declare that they have no conflict of interest.

\section{References}

1. Resnick, A.; Woods, B.; Krapfl, H.; Toth, B. Health outcomes associated with smoke exposure in Albuquerque, New Mexico, during the 2011 Wallow fire. J. Public Health Manag. Pract. JPHMP 2015, 21 (Suppl. 2), S55-S61. [CrossRef] [PubMed]

2. Liu, J.C.; Mickley, L.J.; Sulprizio, M.P.; Dominici, F.; Yue, X.; Ebisu, K.; Anderson, G.B.; Khan, R.F.A.; Bravo, M.A.; Bell, M.L. Particulate Air Pollution from Wildfires in the Western US under Climate Change. Clim. Chang. 2016, 138, 655-666. [CrossRef] [PubMed]

3. Goldizen, F.C.; Sly, P.D.; Knibbs, L.D. Respiratory effects of air pollution on children. Pediatr. Pulmonol. 2016, 51, 94-108. [CrossRef]

4. Nirel, R.; Maimon, N.; Fireman, E.; Agami, S.; Eyal, A.; Peretz, A. Respiratory hospitalizations of children living near a hazardous industrial site adjusted for prevalent dust: A case-control study. Int. J. Hyg. Environ. Health 2015, 218, 273-279. [CrossRef]

5. Caamano-Isorna, F.; Figueiras, A.; Sastre, I.; Montes-Martinez, A.; Taracido, M.; Pineiro-Lamas, M. Respiratory and mental health effects of wildfires: An ecological study in Galician municipalities (north-west Spain). Environ. Health A Glob. Access Sci. Source 2011, 10, 48. [CrossRef]

6. Reid, C.E.; Brauer, M.; Johnston, F.H.; Jerrett, M.; Balmes, J.R.; Elliott, C.T. Critical Review of Health Impacts of Wildfire Smoke Exposure. Environ. Health Perspect. 2016, 124, 1334-1343. [CrossRef] [PubMed]

7. Vaidyanathan, A.; Yip, F.; Garbe, P. Developing an online tool for identifying at-risk populations to wildfire smoke hazards. Sci. Total Environ. 2018, 619-620, 376-383. [CrossRef]

8. Alman, B.L.; Pfister, G.; Hao, H.; Stowell, J.; Hu, X.; Liu, Y.; Strickland, M.J. The association of wildfire smoke with respiratory and cardiovascular emergency department visits in Colorado in 2012: A case crossover study. Environ. Health A Glob. Access Sci. Source 2016, 15, 64. [CrossRef] 
9. Jayachandran, S. Air quality and early-life mortality evidence from Indonesia's wildfires. J. Hum. Resour. 2009, 44, 916-954. [CrossRef]

10. Johnston, F.H.; Purdie, S.; Jalaludin, B.; Martin, K.L.; Henderson, S.B.; Morgan, G.G. Air pollution events from forest fires and emergency department attendances in Sydney, Australia 1996-2007: A case-crossover analysis. Environ. Health A Glob. Access Sci. Source 2014, 13, 105. [CrossRef]

11. Reid, C.E.; Jerrett, M.; Tager, I.B.; Petersen, M.L.; Mann, J.K.; Balmes, J.R. Differential respiratory health effects from the 2008 northern California wildfires: A spatiotemporal approach. Environ. Res. 2016, 150, 227-235. [CrossRef]

12. Wettstein, Z.S.; Hoshiko, S.; Fahimi, J.; Harrison, R.J.; Cascio, W.E.; Rappold, A.G. Cardiovascular and Cerebrovascular Emergency Department Visits Associated With Wildfire Smoke Exposure in California in 2015. J. Am. Heart Assoc. 2018, 7. [CrossRef] [PubMed]

13. Black, C.; Tesfaigzi, Y.; Bassein, J.A.; Miller, L.A. Wildfire smoke exposure and human health: Significant gaps in research for a growing public health issue. Environ. Toxicol. Pharmacol. 2017, 55, 186-195. [CrossRef]

14. Cuchiara, G.C.; Rappenglück, B.; Rubio, M.A.; Lissi, E.; Gramsch, E.; Garreaud, R.D. Modeling study of biomass burning plumes and their impact on urban air quality; a case study of Santiago de Chile. Atmos. Environ. 2017, 166, 79-91. [CrossRef]

15. Rubio, M.A.; Lissi, E.; Jorquera, H.; Salinas, E.; Castro, J.; Cadiz, M. Carbon monoxide concentrations in Santiago City at street levels and their vertical gradient. Environ. Monit. Assess. 2008, 140, 161-173. [CrossRef] [PubMed]

16. Úbeda, X.; Sarricolea, P. Wildfires in Chile: A review. Glob. Planet. Chang. 2016, 146, 152-161. [CrossRef]

17. de la Barrera, F.; Barraza, F.; Favier, P.; Ruiz, V.; Quense, J. Megafires in Chile 2017: Monitoring multiscale environmental impacts of burned ecosystems. Sci. Total Environ. 2018, 637-638, 1526-1536. [CrossRef] [PubMed]

18. Gómez-González, S.; González, M.E.; Paula, S.; Díaz-Hormazábal, I.; Lara, A.; Delgado-Baquerizo, M. Temperature and agriculture are largely associated with fire activity in Central Chile across different temporal periods. For. Ecol. Manag. 2019, 433, 535-543. [CrossRef]

19. Bowman, D.; Moreira-Munoz, A.; Kolden, C.A.; Chavez, R.O.; Munoz, A.A.; Salinas, F.; Gonzalez-Reyes, A.; Rocco, R.; de la Barrera, F.; Williamson, G.J.; et al. Human-environmental drivers and impacts of the globally extreme 2017 Chilean fires. Ambio 2019, 48, 350-362. [CrossRef]

20. Heilmayr, R.; Echeverria, C.; Fuentes, R.; Lambin, E.F. A plantation-dominated forest transition in Chile. Appl. Geogr. 2016, 75, 71-82. [CrossRef]

21. Kousky, C. Impacts of natural disasters on children. Future Child. 2016, 26, 73-92. [CrossRef]

22. INE. Productos Estadísticos, Demográficas y Vitales; INE: Santiago, Chile, 2019.

23. Montoya-Tangarife, C.; de la Barrera, F.; Salazar, A.; Inostroza, L. Monitoring the effects of land cover change on the supply of ecosystem services in an urban region: A study of Santiago-Valparaiso, Chile. PLoS ONE 2017, 12, e0188117. [CrossRef] [PubMed]

24. Garreaud, R.D.; Vuille, M.; Compagnucci, R.; Marengo, J. Present-day south american climate. Palaeogeogr. Palaeoclimatol. Palaeoecol. 2009, 281, 180-195. [CrossRef]

25. Boisier, J.P.; Rondanelli, R.; Garreaud, R.D.; Muñoz, F. Anthropogenic and natural contributions to the Southeast Pacific precipitation decline and recent megadrought in central Chile. Geophys. Res. Lett. 2016, 43, 413-421. [CrossRef]

26. (CR)2 Center for Climate and Resilience Research. Report to the Nation. The 2010-2015 Mega-Drought: A Lesson for the Future; November 2015. Available online: https:/ / www.cr2.cl/eng/wp-content/uploads/2020/07/Mega-drought-Report.pdf (accessed on 30 July 2019).

27. Muñoz, R.C.; Undurraga, A.A. Daytime mixed layer over the Santiago Basin: Description of two years of observations with a lidar ceilometer. J. Appl. Meteorol. Climatol. 2010, 49, 1728-1741. [CrossRef]

28. Barraza, F.; Jorquera, H.; Heyer, J.; Palma, W.; Edwards, A.M.; Munoz, M.; Valdivia, G.; Montoya, L.D. Short-term dynamics of indoor and outdoor endotoxin exposure: Case of Santiago, Chile, 2012. Environ. Int. 2016, 92-93, 97-105. [CrossRef] [PubMed]

29. Cakmak, S.; Dales, R.E.; Gultekin, T.; Vidal, C.B.; Farnendaz, M.; Rubio, M.A.; Oyola, P. Components of particulate air pollution and emergency department visits in Chile. Arch. Environ. Occup. Health 2009, 64, 148-155. [CrossRef] [PubMed]

30. Cakmak, S.; Dales, R.E.; Vidal, C.B. Air pollution and mortality in Chile: Susceptibility among the elderly. Environ. Health Perspect. 2007, 115, 524-527. [CrossRef] [PubMed]

31. Dales, R.E.; Cakmak, S.; Vidal, C.B.; Rubio, M.A. Air pollution and hospitalization for acute complications of diabetes in Chile. Environ. Int. 2012, 46, 1-5. [CrossRef] [PubMed]

32. Dales, R.E.; Cakmak, S.; Vidal, C.B. Air pollution and hospitalization for venous thromboembolic disease in Chile. J. Thromb. Haemost. JTH 2010, 8, 669-674. [CrossRef]

33. Díaz-Robles, L.; Cortés, S.; Vergara-Fernández, A.; Ortega, J.C. Short term health effects of particulate matter: A comparison between wood smoke and multi-source polluted urban areas in Chile. Aerosol Air Qual. Res 2015, 15, 306-318. [CrossRef]

34. Pino, P.; Walter, T.; Oyarzun, M.; Villegas, R.; Romieu, I. Fine particulate matter and wheezing illnesses in the first year of life. Epidemiol. Camb. Mass. 2004, 15, 702-708. [CrossRef] [PubMed]

35. CONAF. Resumen Nacional de Ocurrencia Por Provincias y Comunas; CONAF: Santiago, Chile, 2019.

36. Wood, S.N. Stable and efficient multiple smoothing parameter estimation for generalized additive models. J. Am. Stat. Association. 2004, 99, 673-686. [CrossRef]

37. Rutllant, J.; Garreaud, R. Episodes of Strong Flow down the Western Slope of the Subtropical Andes. Mon. Weather Rev. 2004, 132, 611-622. [CrossRef] 
38. Delfino, R.J.; Brummel, S.; Wu, J.; Stern, H.; Ostro, B.; Lipsett, M.; Winer, A.; Street, D.H.; Zhang, L.; Tjoa, T.; et al. The relationship of respiratory and cardiovascular hospital admissions to the southern California wildfires of 2003. Occup. Environ. Med. 2009, 66, 189-197. [CrossRef] [PubMed]

39. Kunzli, N.; Avol, E.; Wu, J.; Gauderman, W.J.; Rappaport, E.; Millstein, J.; Bennion, J.; McConnell, R.; Gilliland, F.D.; Berhane, K.; et al. Health effects of the 2003 Southern California wildfires on children. Am. J. Respir. Crit. Care Med. 2006, 174, 1221-1228. [CrossRef]

40. Black, C.; Gerriets, J.E.; Fontaine, J.H.; Harper, R.W.; Kenyon, N.J.; Tablin, F.; Schelegle, E.S.; Miller, L.A. Early Life Wildfire Smoke Exposure Is Associated with Immune Dysregulation and Lung Function Decrements in Adolescence. Am. J. Respir. Cell Mol. Biol. 2017, 56, 657-666. [CrossRef] [PubMed]

41. Brown, M.R.G.; Agyapong, V.; Greenshaw, A.J.; Cribben, I.; Brett-MacLean, P.; Drolet, J.; McDonald-Harker, C.; Omeje, J.; Mankowsi, M.; Noble, S.; et al. After the Fort McMurray wildfire there are significant increases in mental health symptoms in grade 7-12 students compared to controls. BMC Psychiatry 2019, 19, 18. [CrossRef]

42. Liu, J.C.; Pereira, G.; Uhl, S.A.; Bravo, M.A.; Bell, M.L. A systematic review of the physical health impacts from non-occupational exposure to wildfire smoke. Environ. Res. 2015, 136, 120-132. [CrossRef]

43. Herrera, A.M.; Cavada Ch, G.; Mañalich, M.J. Pediatric asthma hospitalization in Chile: 2001-2014. Rev. Chil. Pediatr. 2017, 88, 602-607. [CrossRef] [PubMed]

44. Moya Olivares, A.; Villarroel Del Pino, L.; Fierro Tolosa, L.; Foncea Fierro, C.; Caussade Larraín, S. Spirometric values in healthy preschool children. Rev. Chil. Pediatr. 2019, 90, 69-77. [CrossRef] [PubMed]

45. Sapunar, J.; Aguilar-Farías, N.; Navarro, J.; Araneda, G.; Chandía-Poblete, D.; Manríquez, V.; Brito, R.; Cerda, Á. High prevalence of dyslipidemia and high atherogenic index of plasma in children and adolescents. Rev. Med. Chile 2018, 146, 1112-1122. [CrossRef]

46. Faustini, A.; Alessandrini, E.R.; Pey, J.; Perez, N.; Samoli, E.; Querol, X.; Cadum, E.; Perrino, C.; Ostro, B.; Ranzi, A.; et al. Short-term effects of particulate matter on mortality during forest fires in Southern Europe: Results of the MED-PARTICLES Project. Occup. Environ. Med. 2015, 72, 323-329. [CrossRef] [PubMed]

47. Oyarzún, M. Contaminación aérea y sus efectos en la salud. Rev. Chil. Enferm. Respir. 2010, 26, 16-25. [CrossRef]

48. D'Amato, G.; Holgate, S.T.; Pawankar, R.; Ledford, D.K.; Cecchi, L.; Al-Ahmad, M.; Al-Enezi, F.; Al-Muhsen, S.; Ansotegui, I.; Baena-Cagnani, C.E.; et al. Meteorological conditions, climate change, new emerging factors, and asthma and related allergic disorders. A statement of the World Allergy Organization. World Allergy Organ. J. 2015, 8, 25. [CrossRef] [PubMed] 